\title{
HUBUNGAN SUMBER INFORMASI DENGAN PEMAKAIAN KONTRASEPSI DI KELURAHAN MERAK TANGERANG
}

\author{
Siska Santikasari ${ }^{1}$, Puji Laksmini ${ }^{2}$ \\ ${ }^{1}$ STIKes Jayakarta \\ ${ }^{2}$ Universitas Siliwangi \\ siskasantikasari9@gmail.com
}

\begin{abstract}
Abstrak
Kontrasepsi merupakan suatu usaha yang dilakukan untuk mencegah terjadinya kehamilan, serta mengatur jumlah anak yang diinginkan. Kendala yang dihadapi pada pemasangan alat kontrasepsi yaitu belum optimalnya penyampaian informasi secara mandiri maupun kelompok tentang kontrasepsi. Penelitian ini bertujuan mengidentifikasi adanya hubungan antara sumber informasi pada Pasangan Usia Subur (PUS) dengan pemakaian kontrasepsi di kelurahan Merak kabupaten Tangerang. Metode penelitian adalah deskriptif korelasi dengan pendekatan "Cross Sectional". Jumlah sampel sebanyak 66 responden menggunakan teknik Simple Random Sampling, dan uji statistik menggunakan uji ChiSquare. Hasil penelitian di dapatkan nilai p-value $=0.012(<0.05)$, hal ini menunjukkan terdapat hubungan yang signifikan antara sumber informasi dengan pemakaian kontrasepsi di kelurahan Merak Kabupaten Tangerang.
\end{abstract}

\section{Kata Kunci : Sumber Informasi, Pasangan Usia Subur (PUS), Kontrasepsi}

\section{Pendahuluan}

Indonesia memiliki jumlah pasangan usia subur sebanyak 48.536 .690 dengan jumlah peserta KB baru yaitu 6.663 .156 atau 13,73\%. Dari 33 provinsi yang ada di Indonesia, provinsi Banten memiliki urutan kedua dimana jumlah pasangan usia subur nya sebanyak 2.448.052 jiwa, tetapi untuk jumlah peserta $\mathrm{KB}$ baru hanya memiliki peserta 269.608 atau $11,01 \%$ dibandingkan dengan DKI Jakarta yang jumlah pasangan usia subur nya sebanyak 2.031.956, dan untuk jumlah peserta KB baru nya yaitu 518.562 atau 25,52\% (Data \& Informasi Profil Kesehatan Indonesia, 2016).

Berdasarkan jumlah peserta KB baru menurut kabupaten/ kota Provinsi Banten, kabupaten Tangerang menempati peserta KB baru terendah kedua yaitu dengan jumlah pasangan usia subur (PUS) 605.331 dan peserta KB baru 96.666 dengan hasil $16,0 \%$, dibandingkan dengan kabupaten Serang dengan jumlah PUS 260.295 dan jumlah peserta KB 8.030 dengan hasil 3,1\% tetapi untuk jumlah pasangan usia subur di kabupaten Tangerang sendiri memiliki jumlah terbanyak (Profil Kesehatan Provinsi Banten, 2012).

\section{Hasil Laporan Kinerja BKKBN} tahun 2015 menunjukkan bahwa masih banyak kendala yang dihadapi pada pemasangan alat kontrasepsi yaitu kurangnya pengetahuan pasangan usia subur (PUS) mengenai alat kontrasepsi, belum optimalnya penyampaian KIE (Komunikasi, Informasi, Edukasi) secara mandiri maupun kelompok tentang metode kontrasepsi.

Menurut hasil penelitian yang dilakukan oleh Sumariati, R (2013) hubungan peran media massa dalam mempengaruhi sikap terhadap keikutsertaan 
ber-KB dilihat dari variabel tingkat pendidikan, tempat tinggal, masing-masing mempunyai hubungan yang signifikan dengan nilai $p$-value $=0,000 \quad(p<0.05)$. Televisi merupakan media yang paling banyak diperhatikan oleh pemirsa. Media lain yaitu promosi melalui tokoh agama/ masyarakat, dokter, bidan, dan kader KB dapat dijadikan sebagai tempat menyampaikan pesan dan informasi. Berdasarkan fenomena tersebut dirasa penting untuk melakukan penelitian mengenai " Hubungan antara sumber informasi pada pasangan usia subur (PUS) dengan pemakaian kontrasepsi di kelurahan Merak kabupaten Tangerang tahun 2018 "

\section{Tujuan dari penelitian ini adalah :}

a. Mengidentifikasi sumber informasi pasangan usia subur (PUS) tentang pemakaian kontrasepsi.

b. Mengetahui apakah ada hubungan antara sumber informasi pasangan usia subur (PUS) dengan penggunaan kontrasepsi.

\section{Tinjauan Teoritis}

Sumber informasi adalah segala sesuatu yang dapat digunakan untuk menyampaikan informasi dari pengirim ke penerima sehingga dapat merangsang pikiran, perasaan, perhatian, dan minat dari si penerima, atau sumber informasi merupakan segala hal yang dapat digunakan oleh seseorang sehingga mengetahui tentang hal yang baru dan mempunyari ciriciri yaitu dapat dilihat, dibaca, diperlajari, dikaji, dianalisis, dimanfaatkan, serta dikembangkan didalam kegiatan-kegiatan pendidikan, penelitian, dan ditransformasikan kepada orang lain (Rachmayani, 2015).

1. Sumber - sumber Informasi

a. Sumber informasi manusia/ orang.

Untuk mendapatkan informasi dari seorang pakar/ ahli dapat berhubungan secara lisan/ tulisan baik menemui pada saat seminar, diskusi, kongres, dan lain-lain maupun dapat menggunakan ciptaan mereka berupa karya tulis ilmiah. Sumber informasi tersebut meliputi tokoh masyarakat, tenaga kesehatan, ibu PKK, dan kelompok arisan (Priyanto, 2012).

1) Tokoh Masyarakat

2) Keluarga

3) Tenaga Kesehatan

b. Sumber informasi melalui media massa

Media massa adalah alat yang di gunakan dalam penyampaian pesan pesan dari sumber kepada penerima dengan menggunakan alat-alat komunikasi mekanis seperti surat kabar, film, radio, TV, dan lain-lain (Cangara, 2010).

Berdasarkan jenisnya media massa dibagi menjadi dua yaitu media cetak dan media elektornik

1) Media cetak

2) Media Elektronik

3) Media Online

Pasangan Usia Subur (PUS) merupakan pasangan suami istri yang berumur antara 15-49 tahun dimana pasangan (laki-laki dan perempuan) sudah cukup matang dalam segala hal, termasuk fungsi reproduksinya. Pada masa ini pasangan usia subur harus dapat menjaga dan memanfaatkan kesehatan reproduksinya, dan sangat mudah memperoleh keturunan sehingga memerlukan adanya pengaturan kesuburan (fertilitas). Pasangan usia subur di upayakan mampu menekan angka kelahiran dengan metode keluarga berencana (KB ) (Mulyani, 2016).

Berdasarkan teori Green (1980) yang dikutip oleh Rachmayani (2015) terdapat empat faktor yang mempengaruhi seseorang dalam pemakaian kontrasepsi, yaitu:

1. Faktor Pencetus (Predisposisi)
a. Pengetahuan
b. Sikap
c. Umur
d. Pendidikan
e. Tingkat Kekayaan
f. Budaya 
2. Faktor Pendukung (Enabling)
a. Fasilitas Kesehatan
b. Sumber Informasi

3. Faktor Pendorong (Reinforcing)
a. Tokoh Masyarakat
b. Dukungan orang sekitar
c. Petugas kesehatan

4. Faktor lainnya

a. Pekerjaan

\section{Metode Penelitian}

Dalam penelitian ini, peneliti menggunakan metode penelitian deskriptif korelasi dengan pendekatan "Cross Sectional". Variabel independent dalam penelitian ini adalah sumber informasi dan vaiabel dependent adalah pemakaian kontrasepsi. Populasi dalam penelitian ini adalah semua pasangan usia subur yang ada di kelurahan Merak kabupaten Tangerang, total populasi yang ada yaitu 1.745 orang. Penghitungan besar sampel menggunakan rumus uji hipotesis dua proporsi (Ariawan b.

1998) dengan teknik pengambilan sampel secara acak sederhana (Simple random sampling) sejumlah 66 orang.

Kuesioner ini berisi pertanyaan berupa data demografi responden yang meliputi nama inisial, umur, tingkat pendidikan, pekerjaan dan pertanyaanpertanyaan tentang sumber informasi pada pasangan usia subur (PUS) dengan pemakaian kontrasepsi. Kuisioner pada penelitian ini menggunakan penelitian skala Guttman yaitu hanya ada dua jawaban, jika jawaban responden positif seperti ya dengan skor satu (1) dan jika jawaban responden negatif seperti tidak diberikan skor nol (0) (Riduwan, 2008). Analisis data yang digunakan adalah distribusi responden dan uji statistik Chi square.

\section{Hasil Penelitian}

\section{A. Analisis Univariat}

1. Karakteristik Responden

a. Umur

Tabel 5.1

Distribusi Frekuensi Responden Berdasarkan Umur Pada Pasangan Usia Subur (PUS) di Kelurahan Merak Kabupaten Tangerang Bulan April Tahun 2018 (n= 66)

\begin{tabular}{cc}
\hline Umur & Persen $(\%)$ \\
\hline $20-25$ Tahun & 14.7 \\
\hline $26-30$ Tahun & 31.3 \\
\hline $31-35$ Tahun & 15.3 \\
\hline $36-40$ Tahun & 13.3 \\
\hline $41-45$ Tahun & 16.7 \\
\hline$>45$ Tahun & 8.7 \\
\hline Total & 100 \\
\hline
\end{tabular}

Berdasarkan tabel 5.1 menunjukkan bahwa dari 66 responden, sebanyak $(31.3$ $\%)$ berusia 26 - 30 tahun, $(16.7 \%)$ berusia 41 - 45 tahun, $(15.3 \%)$ berusia $31-35$ tahun, $(14.7 \%)$ berumur $20-25$ tahun,
$(13.3 \%)$ berusia $36-40$ tahun, dan $(8.7 \%)$ berusia $>45$ tahun.

c. Tingkat pendidikan

Tabel 5.2

Distribusi Frekuensi Responden Berdasarkan Tingkat Pendidikan Pada Pasangan Usia Subur (PUS) di Kelurahan Merak Kabupaten Tangerang Bulan April Tahun $2018(n=66)$

Tingkat Pendidikan $\quad$ Persen $(\%)$




\begin{tabular}{cc}
\hline SD & 10.0 \\
\hline SMP/ MTS & 28.0 \\
\hline SMA/ SMK & 58.0 \\
\hline Perguruan Tinggi & 4.0 \\
\hline Total & 100 \\
\hline
\end{tabular}

Berdasarkan tabel 5.2 menunjukkan bahwa dari 66 responden, rata-rata tingkat pendidikan pasangan usia subur (PUS) yaitu SMA/ SMK sebanyak (58.0\%), SMP/ MTS sebanyak (28.0\%), SD sebanyak
$(10.0 \%)$, dan perguruan tinggi sebanyak $(4.0 \%)$.

d. Status Pekerjaan

Tabel 5.3

Distribusi Frekuensi Responden Berdasarkan Status Pekerjaan Pada Pasangan Usia Subur (PUS) di Kelurahan Merak Kabupaten Tangerang Bulan April Tahun $2018(n=66)$

\begin{tabular}{cc}
\hline Status Pekerjaan & Persen $(\%)$ \\
\hline Ibu rumah tangga & 79.3 \\
\hline Karyawan swasta & 20.7 \\
\hline Total & 100
\end{tabular}

Berdasarkan tabel 5.3 menunjukkan bahwa dari 66 responden, status pekerjaan pasangan usia subur (PUS) yaitu ibu rumah tangga sebanyak (79.3\%), dan karyawan swasta sebanyak $(20.7 \%)$.

\section{Variabel Independen}

Variabel independen pada penelitian ini adalah sumber informasi yang terdiri dari tokoh masyarakat, tenaga kesehatan, media massa, dan keluarga.

c. Sumber Informasi

Tabel 5.4

Distribusi Frekuensi Responden Berdasarkan Sumber Informasi Pada Pasangan Usia Subur (PUS) di Kelurahan Merak Kabupaten Tangerang Bulan April Tahun $2018(n=66)$

\begin{tabular}{cc}
\hline Sumber Informasi & Persen $(\%)$ \\
\hline Tidak & 4.0 \\
\hline Tokoh Masyarakat & 14.7 \\
\hline Tenaga Kesehatan & 40.7 \\
\hline Media Massa & 22.0 \\
\hline Keluarga & 18.7 \\
\hline Total & 100 \\
\hline
\end{tabular}

Berdasarkan tabel 5.4 menunjukkan bahwa dari 66 responden, sumber informasi yang paling banyak di dapatkan melalui tenaga kesehatan sebanyak (40.7\%), dan yang paling sedikit yaitu tokoh masyarakat sebanyak $(14.7 \%)$.

d. Tokoh Masyarakat

Tabel 5.5

Distribusi Frekuensi Responden Berdasarkan Sumber Informasi dari Tokoh Masyarakat Pada Pasangan Usia Subur (PUS) di Kelurahan Merak Kabupaten Tangerang Bulan April Tahun $2018(n=66)$ 


\begin{tabular}{cc}
\hline Tokoh Masyarakat & Persen $(\%)$ \\
\hline Tidak & 85.3 \\
\hline Tokoh Agama & 1.3 \\
\hline Kader & 12.7 \\
\hline Ketua RT & 0.7 \\
\hline Total & 100 \\
\hline
\end{tabular}

Berdasarkan tabel 5.5 menunjukkan bahwa dari 66 responden, sumber informasi kontrasepsi dari tokoh masyarakat terdiri

e. Tenaga Kesehatan dari kader sebanyak (12.7\%), tokoh agama sebanyak (1.3\%), dan ketua RT sebanyak $(0.7 \%)$.

Tabel 5.6

Distribusi Frekuensi Responden Berdasarkan Sumber Informasi dari Tenaga Kesehatan Pada Pasangan Usia Subur (PUS) di Kelurahan Merak Kabupaten Tangerang Bulan April Tahun $2018(n=66)$

\begin{tabular}{cc}
\hline Tenaga Kesehatan & Persen $(\%)$ \\
\hline Tidak & 59.3 \\
\hline Dokter & 4.0 \\
\hline Bidan & 36.0 \\
\hline Perawat & 0.7 \\
\hline Total & 100 \\
\hline
\end{tabular}

Berdasarkan tabel 5.6 menunjukkan bahwa dari 66 responden, sumber informasi kontrasepsi dari tenaga kesehatan yang paling banyak adalah bidan $(36.0 \%)$, dokter sebanyak $(4.0 \%)$, dan perawat sebanyak $(0.7 \%)$.

f. Media Massa

Tabel 5.7

Distribusi Frekuensi Responden Berdasarkan Sumber Informasi dari Media Massa Pada Pasangan Usia Subur (PUS) di Kelurahan Merak Kabupaten Tangerang Bulan April Tahun $2018(n=66)$

\begin{tabular}{cc}
\hline Media Massa & Persen (\%) \\
\hline Tidak & 78.0 \\
\hline TV & 16.0 \\
\hline Internet & 6.0 \\
\hline Total & 100 \\
\hline
\end{tabular}

Berdasarkan tabel 5.7 menunjukkan bahwa dari 66 responden, sumber informasi kontrasepsi dari media massa yang paling sering adalah Televisi (TV) sebanyak ( $16.0 \%)$, dan internet sebanyak $(6.0 \%)$.

g. Keluarga

\section{Tabel 5.8}

Distribusi Frekuensi Responden Berdasarkan Sumber Informasi dari Keluarga Pada Pasangan Usia Subur (PUS) di Kelurahan Merak Kabupaten Tangerang Bulan April Tahun $2018(n=66)$

\begin{tabular}{cc}
\hline Keluarga & Persen (\%) \\
\hline
\end{tabular}




\begin{tabular}{cc}
\hline Tidak & 81.3 \\
\hline Suami & 2.7 \\
\hline Orangtua & 12.7 \\
\hline Saudara & 3.3 \\
\hline Total & 100 \\
\hline
\end{tabular}

Berdasarkan tabel 5.8 menunjukkan bahwa dari 66 responden, sumber informasi kontrasepsi dari keluarga yang paling banyak di dapat yaitu orang tua sebanyak (12.7\%), saudara sebanyak $(3.3 \%)$, dan suami $(2.7 \%)$.

\section{Variabel Dependen}

Variabel dependen pada penelitian ini adalah pemakaian kontrasepsi

a. Pemakaian kontrasepsi

Tabel 5.9

Distribusi Frekuensi Responden Berdasarkan Sumber Informasi dari Keluarga Pada Pasangan Usia Subur (PUS) di Kelurahan Merak Kabupaten Tangerang Bulan April Tahun $2018(n=66)$

\begin{tabular}{cc}
\hline Pemakaian kontrasepsi & Persen $(\%)$ \\
\hline Tidak & 10.7 \\
\hline Ya & 89.3 \\
\hline Total & 100
\end{tabular}

Berdasarkan

tabel 5.9 menunjukkan bahwa dari 66 responden, pasangan usia subur (PUS) yang memakai kontrasepsi sebanyak (89.3\%).

B. Analisis Bivariat

a. Hubungan antara Sumber Informasi pada Pasangan Usia Subur (PUS) dengan Pemakaian Kontrasepsi

Tabel 5.10

Hubungan antara Sumber Informasi pada Pasangan Usia Subur (PUS) dengan Pemakaian Kontrasepsi di Kelurahan Merak kabupaten Tangerang bulan April tahun $2018(n=66)$

\begin{tabular}{ccccc}
\hline Sumber Informasi & \multicolumn{2}{c}{$\begin{array}{c}\text { Pemakaian } \\
\text { kontrasepsi }\end{array}$} & \multirow{2}{*}{$\begin{array}{c}\text { Total } \\
(\%)\end{array}$} & p-value \\
\cline { 2 - 3 } & $\begin{array}{c}\text { Tidak } \\
(\%)\end{array}$ & $\begin{array}{c}\text { Ya } \\
(\%)\end{array}$ & & \\
& 50 & 50 & 100 & \multirow{2}{*}{0.012} \\
\hline Tidak & 0.0 & 100 & 100 & \\
\hline Tokoh Masyarakat & 11.5 & 88.5 & 100 & \\
\hline Tenaga Kesehatan & 12.1 & 87.9 & 100 \\
\hline Media Massa & 7.1 & 92.9 & 100 & \\
\hline Keluarga & 10.7 & 89.3 & 100 & \\
\hline Total & & &
\end{tabular}

Berdasarkan tabel silang (cross tabulation) di atas dari 66 responden pada Pasangan Usia Subur (PUS) di kelurahan Merak kabupaten Tangerang, di ketahui bahwa yang mendapatkan sumber informasi dari tokoh masyarakat, $(100 \%)$ yang memakai kontrasepsi dan $(0.0 \%)$ tidak memakai kontrasepsi. Sumber informasi 
dari tenaga kesehatan, yang memakai kontrasepsi sebanyak (88.5\%) dan (11.5\%) tidak memakai kontrasepsi. Untuk sumber informasi dari media massa, sebanyak $(87.9 \%)$ yang memakai kontrasepsi dan $(12.1 \%)$ tidak memakaian kontrasepsi. Sedangkan sumber informasi dari keluarga yang memakai kontrasepsi sebanyak $(92.9 \%)$, dan yang tidak memakai kontrasepsi sebanyak (7.1\%).

\section{A. Pembahasan Analisa Univariat}

\section{Karakteristik Responden}

a. Umur

Berdasarkan hasil penelitian di kelurahan Merak kabupaten Tangerang pada tahun 2018 di dapatkan bahwa sebagian besar pasangan usia subur (PUS) berumur 26 - 30 tahun $(31.3 \%)$. Hal ini sejalan dengan penelitian yang dilakukan oleh Anita Lontaan, dkk (2014) yang menyatakan bahwa rata-rata pada usia 20 - 30 tahun $(36 \%)$, umur berperan sebagai faktor intristik yang meliputi struktur organ, serta komposisi biokimiawi termasuk sistem hormonal seorang wanita. Perbedaan ini pada suatu periode umur menyebabkan perbedaan pada kontrasepsi yang dibutuhkan.

b. Pendidikan

Berdasarkan hasil penelitian di kelurahan Merak kabupaten Tangerang pada tahun 2018 di dapatkan bahwa sebagian besar pasangan usia subur (PUS) memiliki tingkat pendidikan menengah yaitu SMA/ SMK (58.0\%), sedangkan tingkat pendidikan terendah yaitu SD $(10.0 \%)$.

Hal ini sesuai dengan penelitian yang dilakukan oleh Rachmayani (2015) yang menyatakan bahwa sebagain besar responden memiliki tingkat pendidikan menengah yaitu

Dari hasil uji statistik di dapatkan hasil $p$-value sebesar 0.012 berarti $p$-value lebih kecil dari $\alpha(0.05)$ sehingga dapat di simpulkan $\mathrm{H}_{0}$ ditolak artinya ada hubungan yang bermakna antara sumber informasi dengan pemakaian kontrasepsi.

\section{Pembahasan}

sebanyak (61.9\%) dan tingkat pendidikan terendah sebanyak (27.0\%).Pendidikan berpengaruh dalam perilaku penggunaan kontrasepsi oleh wanita usia subur (WUS), karena tingkat pendidikan merupakan hal yang penting, termasuk pentingnya dalam keikutsertaan untuk pemakaian kontrasepsi. Jika seseorang berpendidikan tinggi, maka akan lebih luas dan mudah pandangannya untuk menerima ide atau informasi baru sehingga dapat disimpulkan bahwa orang yang memiliki tingkat pendidikan yang tinggi akan memakai alat kontrasepsi (Proverawati, dkk. 2009) dikutip dalam (Rachmayani, 2015).

c. Status Pekerjaan

Berdasarkan hasil penelitian di kelurahan Merak kabupaten Tangerang pada tahun 2018 di dapatkan bahwa sebagian besar pasangan usia subur (PUS) bekerja sebagai karyawan swasta (20.7\%), namun responden yang tidak bekerja juga menunjukkan angka yang cukup tinggi $(79.3 \%)$ responden yang tidak bekerja yaitu sebagai ibu rumah tangga. Menurut hasil penelitian Irwansyah (2016) menunjukkan bahwa pekerjaan responden sebagai karyawan swasta (17.7\%), dan responden yang tidak bekerja $(45.0 \%)$. 
Hal ini sejalan dengan penelitian yang dilakukan oleh Subiyatun, Sri dkk (2011) yang menyatakan bahwa responden responden yang bekerja (65.2\%) dan yang tidak bekerja sebanyak $(75.5 \%)$, pada ibu yang bekerja informasi yang didapatkan akan lebih mudah, ibu juga mempunyai tanggung jawab terhadap pekerjaannya sehingga akan lebih memilih untuk memakai kontrasepsi.Hasil penelitian Sari, Anita Dwi Agustina (2010) mengatakan bahwa ibu yang bekerja adalah ibu yang melakukan aktifitas ekonomi mencari suatu penghasilan baik di sektor formal maupun informal, yang dilakukan secara teratur di luar rumah.

\section{Variabel Independen}

a. Tokoh Masyarakat

Menurut Pusat Pelatihan Gender \& Peningkatan Kualitas Perempuan Badan Koordinasi Keluarga Berencana Nasional (2008)Tokoh masyarakat merupakan seseorang yang berpengaruh dan ditokohkan oleh lingkungannya. Menurut Alfiah, Ismi Dzalva (2015) tokoh masyarakat meliputi Ketua RT, RW, Lurah, tokoh agama, serta kader kesehatan.

Berdasarkan hasil penelitian di kelurahan Merak kabupaten Tangerang pada tahun 2018 di dapatkan bahwa sebagian besar pasangan usia subur (PUS) yang mendapatkan sumber informasi kontrasepsi dari tokoh masyarakat sebesar (14.7\%) yang meliputi kader (12.7\%). Hal ini sesuai dengan hasil penelitian Indriyanti (2011) yang menyatakan bahwa ada pengaruh informasi dari kader sebanyak (25\%) walaupun hanya setiap bulan. Sejalan dengan penelitian yang dilakukan oleh Alfiah, I.D (2015) menunjukkan bahwa sumber informasi dari tokoh masyarakat sebanyak (54.4\%) yang di informasikan oleh kader kesehatan (46.7\%) menyatakan pernah ada kegiatan terkait MKJP yang diselenggarakan oleh kader kesehatan.

b. Tenaga Kesehatan Berdasarkan hasil penelitian di kelurahan Merak kabupaten Tangerang pada tahun 2018 di dapatkan bahwa sebagian besar pasangan usia subur (PUS) yang mendapatkan sumber informasi kontrasepsi dari tenaga kesehatan sebanyak (40.7\%) yang meliputi bidan $(36.0 \%)$. Hal ini sesuai dengan penelitian yang dilakukan oleh Indriyanti (2011) yang menyatakan $46.9 \%$ mendapatkan informasi dari bidan, karena beberapa responden yang sudah memiliki banyak anak dan atas anjuran dokter/ bidan akhirnya responden menggunakan kontrasepsi.

c. Media Massa

Menurut Cangara (2010). Media massa adalah alat yang di gunakan dalam penyampaian pesan - pesan dari sumber kepada penerima dengan menggunakan alat-alat komunikasi mekanis seperti surat kabar, film, radio, TV, dan lain-lain.

Berdasarkan hasil penelitian di kelurahan Merak kabupaten Tangerang pada tahun 2018 di dapatkan bahwa sebagian besar pasangan usia subur (PUS) yang mendapatkan sumber informasi kontrasepsi dari media massa sebanyak $(22.0 \%)$, media massa yang paling sering adalah televisi (TV) sebanyak (16.0\%). Hasil penelitian Irwansyah (2016) menunjukkan mayoritas responden (77.6\%) mengingat slogan iklan 
KB yang pernah ditayangkan di televisi, slogan tersebut berisi " Ayo ikut KB " atau "Dua anak cukup".

Hal ini tidak sejalan dengan penelitian yang dilakukan oleh Indriyanti (2011) yang menyatakan bahwa tidak ada pengaruh media televisi dengan pemakaian kontrasepsi yaitu (3.1\%), Hal ini disebabkan karena mereka lebih sering menonton acara sinetron, serta kurangnya informasi mengenai mekanisme kerja, keuntungan dan kerugian KB yang akan di gunakan. Hampir semua responden mengetahui iklan kontrasepsi atau biasa dikenal dengan KB yang di tayangkan di TV dengan tujuan untuk meningkatkan kesadaran menggunakan $\mathrm{KB}$

d. Keluarga

Berdasarkan hasil penelitian di kelurahan Merak kabupaten Tangerang pada tahun 2018 di dapatkan bahwa sebagian besar pasangan usia subur (PUS) yang mendapatkan sumber informasi dari keluarga (18.7\%) informasi yang didapat adalah dari orang tua (12.7\%). Menurut hasil penelitian Indriyanti (2011) mengatakan bahwa sumber informasi tidak banyak mempengaruhi keputusan untuk memakai kontrasepsi, namun yang

\section{B. Pembahasan Analisa Bivariat}

\section{Hubungan antara Sumber Informasi pada Pasangan Usia Subur (PUS) dengan Pemakaian Kontrasepsi}

Hasil penelitian ini

menunjukkan bahwa responden yang mendapatkan sumber informasi dari tokoh masyarakat, (100\%) yang memakai kontrasepsi dan $(0.0 \%)$ tidak memakai kontrasepsi. Sumber informasi dari tenaga kesehatan, yang paling mempengaruhi keputusan untuk memakai kontrasepsi adalah orang tua dari responden tersebut. Hal ini juga sejalan dengan penelitian Rachmayani (2015) yang mengatakan bahwa bisa saja responden sudah mendapatkan informasi tentang kontrasepsi tersebut dari pendidik sebaya seperti tetangga, atau informasi dari ibu dan lingkungan di keluarganya.

\section{Variabel Dependen}

A. Pemakaian Kontrasepsi

$$
\text { Berdasarkan hasil }
$$

penelitian di kelurahan Merak kabupaten Tangerang pada tahun 2018 di dapatkan bahwa sebagian besar pasangan usia subur (PUS) $89.3 \%$ memakaian alat kontrasepsi. Hal ini sesuai dengan penelitian yang dilakukan oleh Rachmayani (2015) yang menyatakan bahwa $77.9 \%$ wanita usia subur (WUS) memakai alat kontrasepsi. Menurut (Sulistyawati, 2011) tujuan program keluarga berencana adalah membentuk keluarga kecil sesuai dengan kekuatan sosial ekonomi suatu keluarga, dengan cara pengaturan kelahiran anak agar diperoleh suatu keluarga bahagia dan sejahtera yang dapat memenuhi kebutuhan hidupnya.

memakai kontrasepsi sebanyak $(88.5 \%)$ dan $(11.5 \%)$ tidak memakai kontrasepsi. Sumber informasi dari media massa, sebanyak $(87.9 \%)$ yang memakai kontrasepsi dan (12.1\%) tidak memakai kontrasepsi. Sedangkan sumber informasi dari keluarga yang memakai kontrasepsi sebanyak $(92.9 \%)$, dan yang tidak memakai kontrasepsi sebanyak (7.1\%). Berdasarkan uji statistik chisquare di peroleh nilai $p$-value $=$ 0.012 nilai $p$-value ini $<0.05$ maka 
$\mathrm{H}_{0}$ ditolak, dapat disimpulkan bahwa ada hubungan yang bermakna antara sumber informasi dengan pemakaian kontrasepsi dikelurahan Merak kabupaten Tangerang.

Menurut Rachmayani (2015) Sumber informasi merupakan segala hal yang dapat digunakan oleh seseorang sehingga mengetahui tentang hal yang baru dan mempunyari ciri-ciri yaitu dapat dilihat, dibaca, diperlajari, dikaji, dianalisis, dimanfaatkan, serta dikembangkan didalam kegiatankegiatan pendidikan, penelitian, dan ditransformasikan kepada orang lain. Sumber informasi diperoleh dari tokoh masyarakat, tenaga kesehatan, media massa, dan keluarga memiliki peranan yang penting bagi pasangan usia subur (PUS) untuk pemakaian kontrasepsi. Menurut Priyanto (2009) Sumber informasi dapat berupa lembaga atau instansi, orang (dokter, perawat, bidan), buku, dokumen, dan lain-lain. Sumber - sumber informasi dapat berupa 1) informasi manusia/ orang yang terdiri dari tokoh masyarakat, keluarga, dan tenaga kesehatan. 2) informasi melalui media massa, seperti media cetak, media elektronik, maupun media online.

Menurut Purba (2008) dalam Alfiah, I. D (2015) untuk mengubah atau mendidik masyarakat seringkali diperlukan pengaruh dari tokoh atau pemimpin masyarakat, termasuk dalam dukungan sosial yang dapat mempengaruhi penggunaan kontrasepsi adalah dukungan pemimpin dalam komunitas. Dukungan pemimpin dalam komunitas terrsebut meliputi tokoh masyarakat (Ketua RT, RW, Lurah, dll), tokoh agama, dan kader kesehatan.

Berdasarkan hasil penelitian di kelurahan Merak kabupaten Tangerang menyatakan bahwa sumber informasi yang paling berpengaruh pada pemakaian kontrasepsi dari tokoh masyarakat $(100 \%)$ karena KB perlu mendapatkan dukungan masyarakat termasuk tokoh agama, walaupun awalnya mendapat tantangan akhirnya program $\mathrm{KB}$ didukung oleh tokoh agama dengan pehamanan bahwa KB tidak bertentangan dengan agama, dan merupakan salah satu upaya dalam pengaturan masalah kependudukan untuk mengurangi kemiskinan.

Hasil penelitian yang

dilakukan oleh Febriyanti (2011) menunjukkan nilai $p$-value $=0.157$ yang berarti jika nilai $(p=0.157)>\alpha$ 0.05 tidak ada hubungan antara pengaruh dukungan sosial terhadap self efficacy pasangan usia subur (PUS) untuk menjadi peserta KB baru Metode kontrasepsi Medis Operatif (MOW) di desa Sukogidri kecamatan Ledokombo kabupaten Jember tahun 2011.Hal ini sejalan dengan penelitian Alfiah, Ismi Dzalva (2015) menunjukkan nilai $p$-value $=0.937$ yang berarti nilai $(p=0.937)>\alpha 0.05$ tidak ada hubungan yang signifikan antara dukungan pemimpin dalam komunitas dengan penggunaan MKJP di wilayah kerja Puskesmas kecamatan Kalideres.

Menurut Rachmayani (2015) Tenaga kesehatan merupakan individu yang bekerja atau mengabdi di bidang kesehatan, cukup pengetahuan dan keterampilan serta pernah menempuh pendidikan di bidang kesehatan. Sumber informasididapatkan langsung dari tenaga kesehatan yaitu dokter, bidan, dan perawat. Berdasarkan hasil penelitian di kelurahan Merak kabupaten Tangerang sumber informasi yang berpengaruh terhadap pemakaian kontrasepsi dari tenaga kesehatan (88.5\%) yang meliputi bidan. Peran bidan dalam masyarakat sebagai tenaga terlatih pada sistem 
kesehatan Nasional dalam memberi pelayanan, meningkatkan pengetahuan masyarakat, dan meningkatkan penerimaan gerakan keluarga berencana (KB). Rachmayani (2015) mengatakan tenaga kesehatan menjadi salah satu faktor yang sangat penting dalam penyelenggaraan pelayanan kesehatan. Ketersediaan tenaga kesehatan yang memadai dapat memudahkan dalam mendukung perilaku penggunaan kontrasepsi di masyarakat khususnya pada WUS.

Sesuai dengan hasil penelitian Rachmayani (2015) yang menunjukkan nilai $p$-value $=0.018$ yang berarti jika nilai $(p=0.018)<\alpha$ 0.05 ada hubungan antara penggunaan kontrasepsi yang melakukan kunjungan ke fasilitas kesehatan dalam 6 bulan terakhir pada WUS di Sumatera Utara pada tahun 20082012 dengan persentase sebesar $(81.9 \%)$.

Hal ini tidak sejalan dengan penelitian Alfiah, Ismi Dzalva (2015) menunjukkan nilai $p$-value $=1.00$ yang berarti jika nilai $(p=1.00)>\alpha$ 0.05 tidak ada hubungan yang signifikan antara dukungan tenaga kesehatan dengan penggunaan MKJP di wilayah kerja Puskesmas kecamatan Kalideres tahun 2015. Dukungan ini mencakup pemberian saran dari petugas kesehatan untuk menggunakan MKJP, karena tenaga kesehatan dikatakan mendukung jika diberikan kesempatan atau kebebasan untuk memilih kontrasepsi yang akan digunakan. Akseptor yang memperoleh dukungan tenaga kesehatan dan menggunakan non MKJP dapat menjadikan alasan tidak adanya hubungan antara dukungan tenaga kesehatan dengan penggunaan MKJP.

Menurut Cangara (2010) media massa adalah alat yang digunakan dalam penyampaian pesan- pesan dari sumber kepada penerima dengan menggunakan alat-alat mekanis seperti surat kabar, film, radio, $\mathrm{Tv}$, dan lain sebagainya.

Berdasarkan hasil penelitian di

kelurahan Merak kabupaten Tangerang sumber informasi yang berpengaruh terhadap pemakaian kontrasepsi dari media massa $(87.9 \%)$ yaitu televisi.Televisi merupakan media yang paling banyak diperhatikan oleh pemirsa yang dapat dijadikan sebagai tempat menyampaikan pesan dan informasi. Sumber informasi dapat menjadi suatu perantara dalam penyampaian informasi, upaya untuk menampilkan pesan atau informasi yang ingin disampaikan oleh komunikator baik melalui media cetak, media elektronik maupun media online (majalah, TV, radio, internet,dan lain-lain). Akses terhadap sumber informasi adalah hal yang penting dalam meningkatkan pengetahuan dan kepedulian tentang apa yang terjadi di masyarakat.

Berdasarkan hasil penelitian Rachmayani (2015)diperoleh nilai $p$ value $=0.055$ yang berarti nilai $(p=0.055)>\alpha 0.05$ menunjukkan tidak ada hubungan yang signifikan antara sumber informasi media massa dengan perilaku penggunaan kontrasepsi pada WUS di Sumatera Utara.

Menurut Efendi dan Makhfudi (2009) dikutip dalam Wulandari (2016) keluarga merupakan unit terkecil dalam masyarakat yang menjadi penerima asuhan keperawatan. Keluarga memberikan informasi untuk membantu keluarga membuat suatu perubahan. Di dalam keluarga informasi di peroleh dari orang tua.

Berdasarkan hasil penelitian di kelurahan Merak kabupaten Tangerang sumber informasi yang berpengaruh terhadap pemakaian kontrasepsi dari keluarga $(92.9 \%)$ 
adalah orang tua. Di dalam BKKBN dijelaskan bahwa peran orang tua yang salah satu nya adalah peran sebagai konselor, dimana orang tua dapat memberikan gambaran dan pertimbangan nilai positif dan negatif sehingga anak mampu mengambil keputusan yang terbaik.

Hasil penelitian Wulandari,Yunita (2016) diperoleh nilai $p$-value $=0.000$ yang berarti $(\alpha<0.05)$ artinya ada hubungan antara dukungan keluarga dengan keikutsertaan PUS menggunakan MKJP. Dukungan keluarga sangat penting dalam pengaturan kesehatan perawatan primer, karena keluarga memberi informasi untuk membuat perubahan tentang gaya hidup.

Hal ini sesuai dengan penelitian yang di lakukan oleh Indriyanti (2011) yang menyatakan bahwa sumber informasi tidak banyak mempengaruhi keputusan untuk pemakaian kontrasepsi, namun yang paling mempengaruhi keputusan untuk memakai kontrasepsi yaitu kerabat terutama orangtua dari responden itu sendiri.

Berdasarkan hasil penelitian di kelurahan Merak kabupaten Tangerang pernah mendapatkan sumber informasi mengenai kontrasepsi atau KB dari tokoh masyarakat, tenaga kesehatan, media massa, dan keluarga. Diketahui bahwa sumber informasi tersebut memiliki hubungan terhadap pemakaian kontrasepsi, hal ini menjadi ada hubungan antara sumber informasi pada pasangan usia subur (PUS) dengan pemakaian kontrasepsi.Dalam hal pemakaian kontrasepsi, dapat dijelaskan bahwa responden yang mendapatkan sumber informasi cenderung untuk memakai kontrasepsi, sebaliknya responden yang tidak mendapatkan sumber informasi cenderung tidak memakai kontrasepsi.

\section{Kesimpulan Dan Saran}

\section{A. Kesimpulan}

1. Sumber informasi dari tokoh masyarakat yang paling banyak yaitu kader sebanyak (12.7\%), sedangkan dari tenaga kesehatan yaitu bidan sebanyak 36\%, dari media massa : televisi sebanyak $16 \%$, dan sumber informasi dari keluarga : orang tua sebanyak $12,7 \%$.

2. Teridentifikasi adanya hubungan yang signifikan antara sumber informasi pada pasangan usia subur (PUS) dengan pemakaian kontrasepsi di kelurahan Merak kabupaten Tangerang dengan nilai $p$-value $=$ 0.012 .

\section{B. Saran}

\section{BKKBN}

Diharapkan agar upaya-upaya yang telah direncanakan oleh BKKBN dapat menurunkan laju pertumbuhan penduduk dengan cara memberikan informasi mengenai alat kontrasepsi kepada masyarakat dengan lebih melibatkan tokoh masyarakat melalui penyegaran kader, pelatihan kepada tokoh agama, pemberian informasi kepada ketua RT dan lain sebagainya.

\section{Tokoh Masyarakat}

Diharapkan kepada tokoh masyarakat formal maupun informal agar lebih berperan aktif terhadap masyarakat dalam memberikan suatu informasi mengenai kontrasepsi atau KB dan dapat menjalin komunikasi yang baik antara pemerintah dengan masyarakat, terutama untuk kaderkader yang ada di kelurahan dengan kondisi dan situasi masyarakat sehingga mudah untuk dipahami dengan baik.

\section{Peneliti Selanjutnya}

Untuk peneliti selanjutnya di harapkan dapat meneliti lebih dalam mengenai apakah fasilitas kesehatan, 


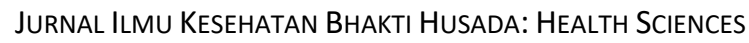
JOURNAL, VOL. 10 NO. 01, JUNI 2019

DOI: https://doi.org/10.34305/jikbh.v10i1.87

dan tempat pelayanan kesehatan yang ada di masyarakat tersebut dapat mempengaruhi PUS dalam pemakaian kontrasepsi.

\section{Daftar Referensi}

Alfiah, Ismi Dzalva. (2015). Faktor-faktor yang berhubungan dengan Penggunaan Metode Kontrasepsi Jangka Panjang di wilayah kerja Puskesmas kecamatan Kalideres tahun 2015 (Bachelor's thesis, UIN Syarif Hidayatullah Jakarta : Fakultas Kedokteran dan Ilmu Kesehatan.

Ariawan, Iwan. (1998). Besar dan Metode Sampel pada Penelitian Kesehatan. Depok : Fakultas Kesehatan Masyarakat, Universitas Indonesia

Arikunto, Suharsimi. (2013).Prosedur Penelitian Suatu

PendekatanPraktik. Jakarta: Rineka Cipta

Asep Syamsul M, Romli. (2012). Jurnalistik Online. Panduan Mengelola Media Online. Bandung : Nuansa Cendikia

BKKBN.

http://aplikasi.bkkbn.go.id/mdk/Bata sanMDK.aspx

BKKBN. (2015). Rencana Stategis Badan Kependudukan dan Keluarga Berencana. Jakarta : BKKBN

Cangara, Hafied. (2010). Pengantar Ilmu Komunikasi. Jakarta : PT Raja Grafindo

Dwi Agustina Sari, Anita. (2010). Hubungan tingkat Pendidikan Formal dengan pemilihan alat Kontrasepsi di Desa Mojodoyong Kedawung Sragen (Doctorial dissertation, Universitas Sebelas Maret)

Febriyanti, Rina. (2011). Pengaruh Dukungan Sosial Terhadap Self Efficacy Pasangan Usia Subur (PUS) untuk menjadi Peserta KB Baru Metode Kontrasepsi Medis Operatif Wanita (MOW). Skripsi.
Jember : Fakultas Kesehatan

Masyarakat Universitas Jember

Hastono, Priyo Sutanto., dkk. (2010). Statistik Kesehatan. Jakarta : Rajawali Pers

Indriyanti, Indah Silvianingrum., dkk. (2011). Sumber informasi yang mempengaruhi keputusan menjadi akseptor KB wanita (Studi kasus di Kelurahan Bandarharjo Semarang). Universitas Diponegoro: Fakultas Kedokteran

Irwansyah, I. (2016). Efek Iklan Televisi Program Keluarga Berencana. Jurnal Komunikasi Untar

Ismail, A W. (2016). Faktor yang mempengaruhi fertilitas di kelurahan tanjung raya kecamatan kedamaian kota bandar lampung (skripsi).

Kemenkes RI. (2013). Riset Kesehatan Dasar; RISKESDAS.Jakarta: Balitbang Kemenkes RI

KemenKes RI. (2014). Pusat data dan analisis data. Jakarta selatan

Kemenkes RI. (2016). Data dan Informasi Profil Kesehatan Indonesia. Jakarta Kemenkes

RI (http://www.depkes.go.id)

KemenKes. (2012). Profil Kesehatan Provinsi Banten. Serang : TIM (http://www.depkes.go.id)

Korompis, Grace E.C., dkk. (2014). Biostatistika Untuk Keperawatan. Jakarta :EGC

Lontaan, A., \& Kusmiyati, K. (2014). Faktor - faktor yang berhubungan dengan Pemilihan Kontrasepsi Pasangan Usia Subur di Puskesmas Damau kabupaten Talaud. JIDAN (Jurnal Ilmiah Bidan)

M. Romli, Asep Syamsul. (2012). Jurnalistik Online: Panduan praktis mengolah media online. Bandung : Nuansa Cendekia

Maiharti, Rinda Ika. (2012). Hubungan Tingkat Pengetahuan Pendidikan dan Pendapatan pada PUS di Kecamatan Jenu dan Kecamatan 


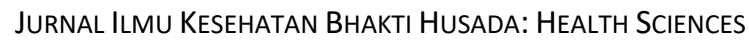
JOURNAL, VOL. 10 NO. 01, JUNI 2019

DOI: https://doi.org/10.34305/jikbh.v10i1.87

Jatirogo Kabupaten Tuban. Swara Bhumi

Mega. (2017). Asuhan Kebidanan Keluarga Berencana. Jakarta : TIM

Mulyani, S., \& Razif, M. (2016). Persepsi Pasangan Usia Subur Terhadap Program Keluarga Berencana (Kb) Di Desa Sungai Kuning Kecamatan Singingi Kabupaten Kuantan Singingi.Jurnal Online Mahasiswa (JOM) Bidang Ilmu Sosial dan Ilmu Politik, 3(1), 1-15.

Notoatmodjo, Soekidjo. (2010). Metodologi Penelitian Kesehatan. Jakarta : Rineka Cipta

Notoatmodjo, Soekidjo. (2012). Metodologi Penelitian Kesehatan. Jakarta : Rineka Cipta

Notoatmodjo, Soekidjo. (2012). Promosi Kesehatan dan Perilaku Kesehatan. Jakarta: Rineka Cipta

PermenKes. (2009). Undang-Undang NO.36 tahun 2009 tentang kesehatan

Priyanto, Agus. (2009). Komunikasi dan Konseling Aplikasi Dalam Sarana Pelayanan Kesehatan Untuk Perawat dan Bidan. Jakarta : Salemba Medika

Pusat Pelatihan Gender dan Peningkatan Kualitas Perempuan Badan Koordinasi Keluarga Berencana. (2008)(https://balatbangbengkulu.fil es.wordpress.com/2010/05/toma.pdf )

Rachmayani, A.N. (2015). Faktor-faktor yang berhubungan dengan Perilaku Penggunaan Kontrasepsi pada Wanita Usia Subur (WUS) di Sumatera Utara (Data SDKI 2012)

Riduwan. (2008). Skala Pengukuran Variabel-Variabel Penelitian.

Bandung: Alfabeta

Sari, Dianti Desita. (2017). Gambaran Tingkat Pengetahuan Keluarga di
Wilayah RT.001/ RW.07 Kelurahan Papanggo Pasca Sosialisasi Keluarga Berencana. Jurnal Akademi Keperawatan Husada Karya Jaya, 3(1).

SDKI. (2012). Survei demografi dan kesehatan Indonesia. (http://kesga.kemkes.go.id/images/p edoman/SDKI\%202012-

Indonesia.pdf)

Sibagariang, Eva Ellya. (2010). Kesehatan Reproduksi Wanita. Jakarta : TIM

Subiyatun, S., Dasuki, D., \& Wahyuni, B. (2011). Hubungan antara Pemberian Informasi dengan Pemilihan Metoda atau Alat Kontrasepsi Rasional (Kajian Data Proyek SM-PFA di Jawa Tengah dan Jawa Timur tahun 2012). Berita Kedokteran Masyarakat

Sugiyono. (2014).Metode Penelitian Pendekatan Kuantitatif,Kualitatif Dan $R \& D$. Bandung: Alfabeta

Sulistyawati, Ari. (2011). Pelayanan Keluarga Berencana. Jakarta : Salemba Medika

Sumariati, R., dkk. (2013). Peran media massa dalam mempengaruhi sikap terhadap keikutsertaan ber-KB (Analisis Data SDKI tahun 2007). Yogyakarta : Universitas Gadjah Mada

Wulandari, Y., Muhammad, T., \& Ridha, A. (2016). Faktor-faktor Yang Mempengaruhi Penggunaan Metode Kontrasepsi Jangka Panjang (MKJP) pada Pasangan Usia Subur di Kabupaten Sambas. Fakultas ilmu kesehatan

Yohana, Yovita, \& Yessica. (2011). Kehamilan \& Persalinan. Edisi 1. Jakarta : Garda Media 